\title{
Clinical Supervision, a Proposal for Ensuring the Effectiveness of English Language Teaching at Public Universities in Colombia
}

\author{
Luz Alba Paba ${ }^{1}$ \\ ${ }^{1}$ Universidad de La Guajira, Colombia \\ Correspondence: Luz Alba Paba, Universidad de La Guajira, Colombia. E-mail: luzalbapaba@uniguajira.edu.co
}

Received: June 21, 2017 Accepted: August 15, 2017 Online Published: August 18, 2017

doi: 10.5539/elt.v10n9p171 URL: http://doi.org/10.5539/elt.v10n9p171

\begin{abstract}
This research is a report on a quantitative study carried out at the English Departments of three public universities in the Caribbean coast of Colombia. Its main purpose was to analyze the strategies English departments coordinators use to enhance the quality of education their institutions provide in terms of bilingualism. The participants were 39 English teachers and 3 English department coordinators. The results from this research revealed that all three universities struggled with their teachers' assessment process, as well as, placed below the national average in their English language proficiency scores. As a result, a plan was designed for a strategy that would successfully meet the goals.
\end{abstract}

Keywords: bilingualism goals, clinical supervision, teacher's assessment

\section{Introduction}

English has become the lingua franca of business, therefore many countries have adopted educational policies designed to promote and help their citizens to become capable to effectively communicate in that language. In Colombia in particular, being able to fluently communicate in English is an important skill employers take into account when hiring any professional regardless of the type of work. With English becoming so relevant for the country and all professionals wanting to succeed, it has also become of great importance in educational terms; all prestigious schools and universities in the country started offering strong English programs and it was just a matter of time before all institutions started following the same path. The country's President and the Minister of Education have been supporting and encouraging these initiatives, however, despite all these good intentions and well thought out government programs there seem to be some unresolved problems impeding the satisfactory achievement of the overall goal,. It is especially evident within the public school system, which as it is attended by middle and lower class students represents a vast majority of the Colombian society.

\section{Literature Review}

\subsection{Alarming Statistics}

Statistics show that Colombia has not achieved its goals when talking about bilingualism of its population; According to Sanchez (2013), global rankings prove that Colombians score very low on international tests. Education First (2013), presents a ranking of countries based on their population's skills in English, with their criteria going from high to very low, and according to this data Argentina places at the highest level within the Latin American countries, while Colombia could only reach a spot within the low level.

The Center of Regional Economic Studies at the Colombian Republic Bank (2013), supports the information provided by Education First, having carried out a study, in which the TOEFL results were used to compare the proficiency index from people around the world. In accordance with these studies, the Latin American countries have in general terms the lowest levels of performance in comparison with other countries around the world, and even within this group Colombia falls far behind the majority of the countries.

\subsubsection{Statistics Showing a Gap between High Class and Middle and Lower Class in Colombia}

According to Fernandez (2009), these statistics are alarming. Thus, the Colombian educational authorities have posed as number one priority to create conditions, in which Colombians can develop communicative competences in English. However, it does not seem to be working as planned. Schools and universities continue to graduate students without the established level of proficiency in English, with very few exceptions found 
exclusively in the most expensive and prestigious educational institutions within the country.

All of the above constitute a great inequality problem in Colombia, not only because it means that the middle and lower class students do not speak English, but mostly because employers are very selective when recruiting potential employees. In a country with too many professionals and too few job opportunities, one of the most important requirements companies are taking into account during the hiring process is the applicant's level of English proficiency.

Consequently all schools and universities within the country have the responsibility to offer an excellent education to all Colombians; the rich should not be getting a better education than the rest of the population. Although completely closing this gap might be a difficult and long term task, we need to start working towards that goal. Colombia cannot continue offering only the wealthy youth the best tools to succeed while giving the rest of the population the leftovers to face a rough and uncertain future.

Fernandez (2009), proposes that learning English has become synonymous with social and economic status in Colombia. Supporting this statement, Sanchez (2003), exposes two fundamental types of disparities regarding Colombian students' skills in English. The first issue comes to light when taking a look at the academic calendars: consistently "calendar b" students obtain significantly higher scores than "calendar a" students. This difference becomes important when we realize that in Colombia the most prestigious, as well as most expensive schools follow the "calendar b", while the public schools and the small private ones, thus slightly more accessible, are on a "calendar a" schedule.

The other important difference emerges when observing the character of the educational institution. It becomes clear that private schools are attaining higher scores than the public ones in the standardized test Colombia uses to measure its high school students knowledge. (Pruebas SABER). In this regard Nuñez, et al. (2002), cited by Sanchez (2013), states that the disparity is statistically meaningful at any level of significance and it's related to the quality of education, the observed contrast between the two types of institutions demonstrates a gap on the effectiveness of the service provided by the two types of institutions.

\subsection{The Ministry of Education Attempts to Solve the Problem}

While trying to correct the problem and, to minimize the gap between the upper class and the middle and lower classes in terms of bilingualism, experts began analyzing all the aspects brought to light by the existing data and came by one important finding, namely that the problem lays not just with the students, but also with teachers. According to Miranda (2014) and his research "National Plan of Bilingualism: The language teacher, the forgotten actor", the problem has its roots in the educational policies. He observes that major deficiencies were found after country-wide evaluation of competence tests taken by teachers within the public school system.

Sanchez (2013), in his paper "Bilingualism in Colombia" states that so far the quality of teachers has not been analyzed. He also assures that this particular aspect has a considerable effect on the students' academic performance. He presents the following graphic to show the results obtained by English teachers in the evaluation carried out by the Colombian Institute in charge of evaluating the quality of education, (ICFES).

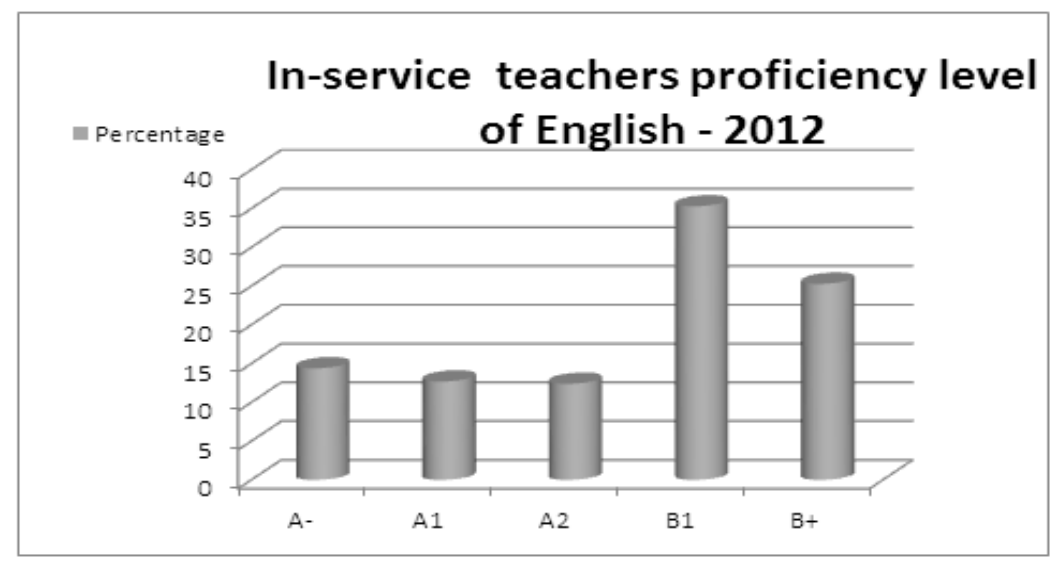

Figure 1. Level of performance in English by Colombian public school English teachers

Results are based on the Common European Framework of Reference for Languages. Source: Sanchez (2013). 
This figure brings to public view one fundamental issue in Colombia's foreign language education: the qualifications of teachers are relatively low according to Barón and Bonilla (as cited in Sanchez, 2013) (p. 20). It is evident that no one scored B2 and only $35 \%$ got a B1, therefore, the very low proficiency levels of students can be explained in a large degree by the fact that a vast number of English teachers in Colombia themselves do not reach high levels of proficiency.

\subsection{The Current Situation in Higher Education Institutions}

Now, to take a closer look at universities in Colombia: Colombia's bilingualism plan encompasses elementary and secondary schools only, and is exclusive of universities, giving them instead an autonomy in that regard, some of which might not be using accordingly.

A supervision plan is recommended for higher education institutions to assure the effectiveness of their practice, but one problem arises when proposing a supervision plan, teachers fear supervision since it has connotations of evaluation and punishment. Most teachers feel uncomfortable with the idea of being supervised and it's not their fault, history has proved them right for many years.

\subsection{Current Approach to Educational Supervision}

Sullivan and Glanz (2013) indicate that in the $18^{\text {th }}$ century educational supervision was conceived as a process in which inspectors (currently known as supervisors) visited schools to collect information of the teaching practice. Their methods of supervision accentuated rigorous control and surveillance of school facilities, they essentially inspected teachers' classroom looking for mistakes.

During the second half of the $19^{\text {th }}$ century a more organized educational system emerged; the quality of supervision would not improve, though. According to Tanner and Tanner (1987) the supervision remained as an inspection process. Supervisors using inspectional practices did not perceive positively the proficiency of most teachers. For instance, Sullivan and Glanz (2013) express that in the $19^{\text {th }}$ century educators were looked by supervisors as incompetent and "that dictatorial practices in supervision still predominated"

Waite (2015) expresses that the greatest obstacle for a supervision that improves teaching is "the sour taste left in teachers' mouth from having been observed by their principal or other administrators" (p. 56). According to him teachers benefit from supervision and even appreciate it when it is done well, to help them grow, not punish them.

\subsection{Clinical Supervision, a Possible Solution}

The clinical supervision is defined as the process of formative assessment that involves a cycle composed of planning conferences, class observations and feedback conferences. This type of supervision aims at improving the teaching practices.

Villar (as cited in Sanchez, 1993), defines it as "a method that can help teachers discover their own knowledge of practice while reflecting on it, combining the clinical supervision with the epistemology of practice" (p. 71).

Furthermore, within the clinical supervision model the supervisor and the supervised are engaged in team work, where they are both committed to achieve a common goal: to enhance the supervised teacher's teaching skills, through a reflective process, using for this purpose objective information from classroom observation and taking as a starting point the supervised teacher's own concerns and expectations.

In the clinical supervision as explained by Acheson and Gall (2003), the supervised teacher "is always viewed as a professional who is actively seeking greater expertise and the focus is on strengths and needs". The purpose of clinical supervision is never to collect information about the quality of performance to stay in a basic phase of rewards - punishment as it usually happens in regular supervision processes. Handal and Lauvas (as cited in Sanchez, 1993), suggest that the primary purpose of clinical supervision is to attain teachers with a consistent, explicit and relevant technique as a basis for decision-making and performance in teaching practice.

On account on the fact that the clinical supervision considers the supervised teacher as a "professional seeking greater expertise", it grants him/her a crucial role on this process, hence the supervisors do not point out mistakes or determine the improvement goals, instead of that they encourage the supervised to analyze their teaching practices and identify the weak areas to creatively think of effective ways to turn weakness into strengths.

\section{Method}

This research was conducted in three public universities located on the Colombian Caribbean coast. The aim was to analyze the strategies English department coordinators were using to enhance the quality of education offered by their institutions. This study started with the conviction that it is an important responsibility of English 
department coordinators to make sure teachers are well trained to face the challenge posed by the Ministry of Education in terms of bilingualism and, to stimulate them to maintain a reflective attitude towards their own practices.

One important hypothesis of this research was the existence of inconsistencies in the approach the English department coordinators take towards their supervising role. This research intended to critically examine the strategies those coordinators use to ensure the accomplishment of the goal. This study also considered that the failure at doing so is not a problem of students, but of the whole education system including students, teachers, school administrators and educational authorities. Therefore, it began by verifying exactly what the English department coordinators did in this regard at public universities located in regions far from major urban centers.

\subsection{Research Design}

As a descriptive study the research design aimed to delineate the supervision actions the English department coordinators were implementing in order to successfully achieve their bilingualism goals. Those actions executed by English department coordinators were analyzed in the light of the criteria explained by the clinical supervision model, in which Acheson and Gall (2003), stress that every educational supervisor should provide teachers with objective feedback on their current performance, as well as, guide them in the development of instructional skills, and finally, foster a positive attitude towards the need for permanent professional growth.

The data collection was also carried out through a cross-sectional study which, according to Hernández et al. (2010), is a quantitative research strategy executed at one time point, and which purpose is to analyze the variables impact and interaction without any external manipulation.

A descriptive, cross-sectional study was chosen for this research, being considered that the purpose of the study was not to manipulate the conditions, not to study the problem historically but to analyze the current situation to design an improvement plan leading to the achievement of the goals.

\subsection{Participants}

This research was developed for a finite population; therefore, a population census was performed. The participants in this study were 3 English department coordinators and 39 English teachers who constitute the entire population of coordinators and teachers within the 3 universities where the study took place.

\subsection{Data Collection Instruments}

To assure the validity and reliability of the data collected a Likert-type scale was used. This scale was useful to collect information about the way English department coordinators were ensuring the quality of the education imparted in their programs by supervising their teachers and helping them improve their practice.

In order to obtain the most objective data, two different questionnaires were used, one for teachers and one for English department coordinators, taking into consideration that they have different perspectives regarding the same topic.

\section{Results and Discussion}

The process of data collection began with looking for the type of existing supervision within the English programs at those universities. The first important finding was that there was no established way to supervise teacher's practices at any of the universities studied, according to the data collected. The supervision process was primarily limited to occasional classroom observations in a small part of the study population. These classroom observations had no established protocol. On this subject the English department coordinators admitted to a lack of procedures, while teachers expressed their discomfort about the role they played.

Teachers seemed to be feeling excluded in the assessment process, the same way they had been feeling excluded in many different aspects of the Colombian bilingualism project, as Miranda (2014), states in his research "Implementation of the Bilingualism National Plan: The Language Teacher, the forgotten actor".

Furthering in the field of supervising and evaluating teachers' performance through classroom observations, the clinical supervision model postulates that the process must begin with a planning conference. In this planning conference, both, the supervisor and the supervised establish the purpose of the observation, the technique that is going to be used and the specific behaviors that are going to be evaluated. I strongly believe that following the principles of the clinical supervision would strengthen the process of supervision, turning it into a permanent growing process.

Having verified the first aspect and analyzed the fact that supervision as a formal process essentially does not exist, I wondered what tools were used to evaluate teachers' performance. What was found was that at the 
universities shaping the population of this study the only formal source of information the coordinators had in order to evaluate teacher's execution and effectiveness was a general online instrument the universities used to evaluate the performance of all of their teachers without observing the differences between the subjects taught. It is universally acknowledged that one cannot use the same measure for all teachers, especially at a university level, as it will never be the same teaching such diverse subjects as for example Colombian ethnology and English as a Foreign Language.

Moreover, a questionnaire was being filled by students at the end of each semester. In this questionnaire, students offered information regarding topics such as teaching strategies, teacher's subject knowledge, teacher-student rapport, among others. However, many things affect the reliability of the results. First and foremost, students do not have any teaching related knowledge or training to accurately assess teachers' performance, secondly, students' judgment could be affected by how well they did on the subject and, finally students are never informed about the purposes of the questionnaire or the correct way to fill it out.

According to the University of California UCLA (2015) teacher's manual, evaluating the effectiveness of teaching has many nuances that include curriculum, course development, monitoring of student performance, among many others; therefore the university states in the teacher's manual that a single tool to evaluate teacher's performance is not enough. In accordance with the UCLA statement, this assessment must include a variety of objective tools that ensure the reliability of the results.

As a conclusion to this specific point an asseveration must be made: to have accurate results on teachers' performance evaluation, universities need to make sure that student's judgment is not the only data source they are relying on. According to the UCLA (2015) and Acheson and Gall (2003) students' evaluation of teachers should be only one in a rich variety of instruments to assess such a complex task as it is to be a teacher. The UCLA (2015) also states that teachers should be given the responsibility of being an active part in this evaluation and permanent improvement process.

Analyzing the information discussed above, it becomes clear that the public institutions shaping the study population present significant struggles in the supervision process, however, the question remains whether it actually affects the achievement of the learning objectives. Looking at the most important test used in Colombia to evaluate college students in specific areas of abilities (PRUEBAS SABER PRO), the results for these higher education institutions are not good. According to several studies, (Bogoya, 2013; Lemos, 2014; Rodriguez, 2013), the students from these universities have very low levels of performance in English, placing below Colombia's national average.

In order to overcome the current obstacles, these universities need to critically analyze their processes conductive to effectively offering their students the quality of education they deserve and the Ministry of Education demands in terms of bilingualism. According to the Colombian Ministry of Education (2015), it is expected from all higher education institutions within the country to design and implement improvement plans that result in a superior performance of students on tests and, of course, in their later professional life.

To suit this requirement one proposal is presented: implementation of an adapted version of the clinical supervision model. It is a well-known fact that taking a model that worked in a different society with different needs and particularities is never a good idea. However, analyzing the benefits of an effective model and adapting it so it can work for a community in which it is needed might be the way to assure the accomplishment of the bilingualism goals.

The clinical supervision presents a type of supervision that is very much against everything that we think of in terms of supervision, in the words of Goldhammer (as cited in Acheson \& Gall, 2003), the clinical supervision is "fundamentally humane, emancipated from the dogma and authoritarianism and vested interests of administration... that have typified much of the supervision we have known before". (p. 3), I strongly believe that a supervision based on teacher's growth instead of teacher's punishment, can definitely work towards achieving the unachievable.

Bearing this in mind and given the results teachers scored on the evaluations conducted by the Ministry of Education, I consider this guidance system to be most certainly a method institutions having problems with accomplishing their bilingualism ambitions should adopt. Recognizing that the foundations and goals of the clinical supervision match the needs of the study population, I strongly recommend its use to overcome the obstacles in their process to achieve the bilingualism objectives.

The table below presents the recommended plan. On account of the lack of a supervision protocol, the problems at achieving the bilingualism goals and the teachers' perception of the current supervision practices as inconsistent 
and not beneficial, the proposal includes an organized supervision protocol as well as a program of permanent professional growth.

The scheme is based on the thesis that supervisors are not meant to look for errors as it was used and still is in traditional supervision practices, they must look for areas to be improved and also for strengths to be taken to the next level. In this process teachers will grow professionally and the bilingualism goals will be achieved.

In accordance, the plan includes training in clinical supervision because coordinators and supervisors need to be sensitized and well trained to apply the model effectively, it also presents all the phases of the clinical supervision adapted to the specific population and finally includes a program of permanent professional growth because reflective dialogues not just with supervisors but with other teachers will extend their expertise and therefore improve their teaching practices.

Table 1. Clinical supervision plan finding: lack of a supervision protocol

Finding: Lack of a Supervision protocol

\begin{tabular}{|c|c|c|c|c|c|c|}
\hline \multirow[b]{2}{*}{$\begin{array}{l}\text { IM P ROVEM ENT } \\
\text { ACTION }\end{array}$} & \multirow[b]{2}{*}{$\begin{array}{c}\text { IMPROVEMENT } \\
\text { ACTION'S PURPOSE }\end{array}$} & \multirow[b]{2}{*}{ ACTIVITIES } & \multicolumn{2}{|c|}{ RESOURCES } & \multirow[b]{2}{*}{ INDICATOR } & \multirow{2}{*}{$\begin{array}{c}\text { SUPPORT } \\
\text { FOR } \\
\text { VERIFICATION }\end{array}$} \\
\hline & & & $\begin{array}{l}\text { PHYSICAL } \\
\text { RESOURCES }\end{array}$ & $\begin{array}{c}\text { HUM AN } \\
\text { RESOURCES }\end{array}$ & & \\
\hline \multirow{2}{*}{$\begin{array}{l}\text { Training according } \\
\text { to the clinical } \\
\text { supervision mo del }\end{array}$} & \multirow{2}{*}{$\begin{array}{l}\text { Provide teachers and } \\
\text { coordinators with the } \\
\text { necessary information } \\
\text { about this type of } \\
\text { educational supervision } \\
\text { that will ensure an optimal } \\
\text { execution }\end{array}$} & $\begin{array}{l}\text { 1training session for } \\
\text { coordinators }\end{array}$ & $\begin{array}{l}\text { As required by } \\
\text { the expert }\end{array}$ & $\begin{array}{l}\text { An expert in clinical } \\
\text { supervision }\end{array}$ & $\begin{array}{l}\text { A completed } \\
\text { session }\end{array}$ & $\begin{array}{c}\text { Attendance lists } \\
\text { and photographic } \\
\text { evidence }\end{array}$ \\
\hline & & $\begin{array}{c}\text { 1session to } \\
\text { familiarize the } \\
\text { teachers with the } \\
\text { plan }\end{array}$ & $\begin{array}{l}\text { As required by } \\
\text { the expert }\end{array}$ & $\begin{array}{l}\text { An expert in clinical } \\
\text { supervision }\end{array}$ & $\begin{array}{l}\text { A completed } \\
\text { session }\end{array}$ & $\begin{array}{c}\text { Attendance lists } \\
\text { and photographic } \\
\text { evidence }\end{array}$ \\
\hline \multirow{5}{*}{$\begin{array}{l}\text { Implementation of } \\
\text { the clinical } \\
\text { supervision } \\
\text { techniques }\end{array}$} & \multirow{5}{*}{$\begin{array}{c}\text { Assure an objective } \\
\text { evaluation of teacher's } \\
\text { performance }\end{array}$} & $\begin{array}{l}\text { Perform reliability } \\
\text { and validity study of } \\
\text { the currently used } \\
\text { tools. }\end{array}$ & $\begin{array}{c}\text { Paper and } \\
\text { software required } \\
\text { by the team in } \\
\text { charge of the } \\
\text { process } \\
\end{array}$ & \begin{tabular}{|c|} 
Project Leader and \\
Researcher \\
Analyst. \\
Pollsters and \\
Tabulators \\
\end{tabular} & $\begin{array}{l}\text { 1reliability and } \\
\text { validity study } \\
\text { completed. }\end{array}$ & $\begin{array}{l}\text { 1Report with the } \\
\text { results of the study }\end{array}$ \\
\hline & & $\begin{array}{c}\text { Make changes to } \\
\text { the current tool if } \\
\text { needed. }\end{array}$ & $\begin{array}{l}\text { As required by } \\
\text { the expert }\end{array}$ & $\begin{array}{l}\text { The professional } \\
\text { the institution has in } \\
\text { charge of this task } \\
\text { teaming up with the } \\
\text { English program } \\
\text { coordinator and a } \\
\text { gro up of English } \\
\text { teachers. }\end{array}$ & $\begin{array}{c}\text { 1rating scale } \\
\text { ready to be } \\
\text { presented and } \\
\text { used }\end{array}$ & $\begin{array}{c}\text { 1report with } \\
\text { information about } \\
\text { the changes made } \\
\text { to the tool }\end{array}$ \\
\hline & & $\begin{array}{c}\text { Make students } \\
\text { aware about the } \\
\text { importance of } \\
\text { evaluating their } \\
\text { teachers in a } \\
\text { responsible and } \\
\text { objective way } \\
\end{array}$ & $\begin{array}{c}\text { A place to gather } \\
\text { students }\end{array}$ & $\begin{array}{l}\text { English program } \\
\text { coordinator, } \\
\text { coordinators of all } \\
\text { departments at the } \\
\text { university }\end{array}$ & $\begin{array}{c}\text { 1awareness } \\
\text { session } \\
\text { developed with } \\
\text { students in } \\
\text { every } \\
\text { department }\end{array}$ & $\begin{array}{c}\text { Attendance lists } \\
\text { and photographic } \\
\text { evidence }\end{array}$ \\
\hline & & $\begin{array}{c}\text { Select an } \\
\text { appropriate } \\
\text { combination of the } \\
\text { techniques } \\
\text { proposed by the } \\
\text { clinical supervision } \\
\text { model. }\end{array}$ & $\begin{array}{l}\text { As required by } \\
\text { the team in } \\
\text { charge }\end{array}$ & $\begin{array}{l}\text { Supervisors and } \\
\text { English program } \\
\text { coordinator }\end{array}$ & $\begin{array}{l}\text { Minutes } \\
\text { reporting the } \\
\text { decisions the } \\
\text { team made. }\end{array}$ & Minutes \\
\hline & & $\begin{array}{c}\text { Implement an } \\
\text { appropriate } \\
\text { combination of the } \\
\text { techniques } \\
\text { proposed by the } \\
\text { clinical supervision } \\
\text { model. }\end{array}$ & $\begin{array}{l}\text { As required by } \\
\text { the supervisor }\end{array}$ & $\begin{array}{l}\text { Supervisors and } \\
\text { English program } \\
\text { coordinator }\end{array}$ & $\begin{array}{l}\text { Semiannual } \\
\text { report of the } \\
\text { process }\end{array}$ & Reports \\
\hline $\begin{array}{l}\text { Implementation of } \\
\text { the planning } \\
\text { conference }\end{array}$ & $\begin{array}{l}\text { Ensure an optimal planning } \\
\text { process that guarantees } \\
\text { the definition of appropriate } \\
\text { goals and a relationship of } \\
\text { trust, co mfort and respect } \\
\text { between the supervisor and } \\
\text { the supervised teacher. }\end{array}$ & $\begin{array}{l}\text { 1semiannual } \\
\text { planning conference } \\
\text { with every teacher }\end{array}$ & $\begin{array}{l}\text { 1o ffice for the } \\
\text { conference to } \\
\text { take place }\end{array}$ & $\begin{array}{l}\text { Supervisor and } \\
\text { Supervised }\end{array}$ & $\begin{array}{c}\text { 1conference } \\
\text { per teacher } \\
\text { every semester }\end{array}$ & $\begin{array}{l}\text { Form where the } \\
\text { supervisor keeps } \\
\text { track of the } \\
\text { planning } \\
\text { conferences } \\
\text { develo ped, } \\
\text { supervised } \\
\text { teachers should } \\
\text { sign every session. }\end{array}$ \\
\hline $\begin{array}{l}\text { Implementation of } \\
\text { the feedback } \\
\text { conference }\end{array}$ & $\begin{array}{l}\text { Offer teachers a feedback } \\
\text { from the data collected } \\
\text { through the classroom } \\
\text { observation and guide } \\
\text { him/her to define } \\
\text { improvement goals. }\end{array}$ & $\begin{array}{l}\text { 1semiannual } \\
\text { feedback } \\
\text { conference with } \\
\text { every teacher }\end{array}$ & $\begin{array}{l}\text { 1o ffice for the } \\
\text { conference to } \\
\text { take place }\end{array}$ & $\begin{array}{l}\text { Supervisor and } \\
\text { Supervised }\end{array}$ & $\begin{array}{c}\text { 1conference } \\
\text { per teacher } \\
\text { every semester }\end{array}$ & $\begin{array}{l}\text { Form where the } \\
\text { supervisor keeps } \\
\text { track of the } \\
\text { feedback } \\
\text { conferences } \\
\text { developed, } \\
\text { supervised } \\
\text { teachers should } \\
\text { sign every session }\end{array}$ \\
\hline
\end{tabular}

Source: Paba (2017). 
Table 2. Clinical supervision plan

Finding: weaknesses in the class observation process

\begin{tabular}{|c|c|c|c|c|c|c|}
\hline \multirow[b]{2}{*}{$\begin{array}{l}\text { IM P ROVEM ENT } \\
\text { ACTION }\end{array}$} & \multirow[b]{2}{*}{$\begin{array}{c}\text { IM PROVEMENT } \\
\text { ACTION'S P URPOSE }\end{array}$} & \multirow[b]{2}{*}{ ACTIVITIES } & \multicolumn{2}{|c|}{ RESOURCES } & \multirow[b]{2}{*}{ INDICATOR } & \multirow[b]{2}{*}{$\begin{array}{c}\text { SUPPORT } \\
\text { FOR } \\
\text { VERIFICATION }\end{array}$} \\
\hline & & & $\begin{array}{c}\text { PHYSICAL } \\
\text { RESOURCES }\end{array}$ & $\begin{array}{c}\text { HUMAN } \\
\text { RESOURCES }\end{array}$ & & \\
\hline \multirow{3}{*}{$\begin{array}{l}\text { Designing a class } \\
\text { observation } \\
\text { procedure according } \\
\text { to the model of } \\
\text { Clinical Supervision }\end{array}$} & \multirow{3}{*}{$\begin{array}{c}\text { Ensure an optimal } \\
\text { implementation of class } \\
\text { observations }\end{array}$} & $\begin{array}{c}\text { Training for } \\
\text { Supervisors and } \\
\text { English program } \\
\text { coordinators about } \\
\text { the class } \\
\text { observation } \\
\text { techniques } \\
\text { proposed by the } \\
\text { clinical supervision } \\
\text { model }\end{array}$ & $\begin{array}{l}\text { As required by } \\
\text { the expert }\end{array}$ & $\begin{array}{l}\text { An expert in clinical } \\
\text { supervision }\end{array}$ & $\begin{array}{l}\text { 1training } \\
\text { session } \\
\text { completed }\end{array}$ & $\begin{array}{l}\text { Attendance list, } \\
\text { photographic } \\
\text { evidence }\end{array}$ \\
\hline & & $\begin{array}{c}2 \text { class o bservations } \\
\text { every semester per } \\
\text { teacher. }\end{array}$ & $\begin{array}{l}\text { As required by } \\
\text { the supervisor }\end{array}$ & Supervisors & $\begin{array}{c}2 \text { class } \\
\text { observations } \\
\text { per teacher } \\
\text { every semester }\end{array}$ & $\begin{array}{l}\text { Data collection } \\
\text { forms filled out }\end{array}$ \\
\hline & & $\begin{array}{l}\text { Selection of tools, } \\
\text { schedules and } \\
\text { behaviors to be } \\
\text { analyzed in } \\
\text { conjunction with the } \\
\text { supervised teacher }\end{array}$ & None & Supervisors & $\begin{array}{l}\text { It will take place } \\
\text { within the } \\
\text { planning } \\
\text { conference }\end{array}$ & $\begin{array}{l}\text { Form where the } \\
\text { supervisor keeps } \\
\text { track of the } \\
\text { planning } \\
\text { conference. }\end{array}$ \\
\hline
\end{tabular}

Source: Paba (2017)

Table 3. Clinical Supervision Plan

Finding: Teachers are not familiar with the criteria used to evaluate their performance

\begin{tabular}{|c|c|c|c|c|c|c|}
\hline \multirow[b]{2}{*}{$\begin{array}{l}\text { IM P ROVEM ENT } \\
\text { ACTION }\end{array}$} & \multirow[b]{2}{*}{$\begin{array}{c}\text { IMPROVEMENT } \\
\text { ACTION'S PURPOSE }\end{array}$} & \multirow[b]{2}{*}{ ACTIVITIES } & \multicolumn{2}{|c|}{ RESOURCES } & \multirow[b]{2}{*}{ INDICATOR } & \multirow{2}{*}{$\begin{array}{c}\text { SUPPORT } \\
\text { FOR } \\
\text { VERIFICATION }\end{array}$} \\
\hline & & & $\begin{array}{l}\text { PHYSICAL } \\
\text { RESOURCES }\end{array}$ & $\begin{array}{c}\text { HUMAN } \\
\text { RESOURCES }\end{array}$ & & \\
\hline $\begin{array}{c}\text { Familiarization } \\
\text { aimed at teachers } \\
\text { about the criteria and } \\
\text { conditions directing } \\
\text { the evaluation (of } \\
\text { teachers' } \\
\text { performance) done } \\
\text { by students }\end{array}$ & $\begin{array}{l}\text { Help teachers fully } \\
\text { understand how they are } \\
\text { going to be evaluated by } \\
\text { students and the way it } \\
\text { impacts their overall } \\
\text { assessment. }\end{array}$ & $\begin{array}{c}\text { Familiarization } \\
\text { aimed at teachers } \\
\text { about the criteria and } \\
\text { conditions directing } \\
\text { the evaluation (of } \\
\text { teachers' } \\
\text { performance) done } \\
\text { by students }\end{array}$ & $\begin{array}{l}\text { 1place that } \\
\text { meets the } \\
\text { requirements of } \\
\text { space and } \\
\text { technological } \\
\text { tools needed to } \\
\text { perform the } \\
\text { activity } \\
\text { according to } \\
\text { each particular } \\
\text { case }\end{array}$ & $\begin{array}{l}\text { English program } \\
\text { coordinator }\end{array}$ & $\begin{array}{l}\text { 1session } \\
\text { completed }\end{array}$ & $\begin{array}{c}\text { Attendance lists } \\
\text { and pho tographic } \\
\text { evidence }\end{array}$ \\
\hline
\end{tabular}

Source: Paba (2017) 
Table 4. Clinical Supervision Plan

Finding: High Self-assessment of teacher effectiveness in contrast with low proficiency levels of students

\begin{tabular}{|c|c|c|c|c|c|c|}
\hline \multirow[b]{2}{*}{$\begin{array}{l}\text { IM PROVEM ENT } \\
\text { ACTION }\end{array}$} & \multirow[b]{2}{*}{$\begin{array}{c}\text { IMPROVEMENT } \\
\text { ACTION'S PURPOSE }\end{array}$} & \multirow[b]{2}{*}{ ACTIVITIES } & \multicolumn{2}{|c|}{ RESOURCES } & \multirow[b]{2}{*}{ INDICATOR } & \multirow{2}{*}{$\begin{array}{c}\text { SUPPORT } \\
\text { FOR } \\
\text { VERIFICATION }\end{array}$} \\
\hline & & & $\begin{array}{l}\text { PHYSICAL } \\
\text { RESOURCES }\end{array}$ & $\begin{array}{c}\text { HUMAN } \\
\text { RESOURCES }\end{array}$ & & \\
\hline $\begin{array}{c}\text { Program of } \\
\text { permanent } \\
\text { professional growth }\end{array}$ & $\begin{array}{l}\text { Promote the reflective } \\
\text { dialogue between teachers } \\
\text { to improve their own } \\
\text { teaching practices }\end{array}$ & $\begin{array}{l}\text { 1Program of } \\
\text { permanent } \\
\text { professional growth }\end{array}$ & $\begin{array}{l}\text { As requested by } \\
\text { the team } \\
\text { responsible for } \\
\text { designing and } \\
\text { leading the } \\
\text { program }\end{array}$ & $\begin{array}{l}\text { English program } \\
\text { coordinator }\end{array}$ & $\begin{array}{l}\text { 1Program of } \\
\text { permanent } \\
\text { professional } \\
\text { growth } \\
\text { developed }\end{array}$ & $\begin{array}{l}\text { Attendance lists } \\
\text { and photographic } \\
\text { evidence } \\
\text { Semiannual } \\
\text { recollections of } \\
\text { the outcomes } \\
\text { from those } \\
\text { "permanent } \\
\text { professional } \\
\text { growth" sessions }\end{array}$ \\
\hline
\end{tabular}

Source: Paba (2017).

\section{Conclusions}

In order to provide a comprehensive outlook of the manner the researched problem was addressed, the following conclusions were derived:

The universities shaping the study population are currently not achieving their bilingualism goals; they are below the national average which according to Sanchez (2003), is already low in comparison with most countries worldwide.

There is no supervision protocol at any of the universities studied. The supervision process consists of nothing more than basic classroom observations that do not follow any established procedure.

The only objective tool that is being systematically used to assess teacher's performance is the online rating scale filled out by students, which used in isolation is certainly not enough to evaluate such a complex process like teaching. Besides, students are never taught the proper way to do the critical task that is being entrusted in their hands.

The clinical supervision foundations and purposes meet the needs and objectives of these specific institutions, so it could definitely be a good alternative plus a smart choice to incorporate this type of supervision in their current plans to achieve the bilingualism goals.

Finally, it is hoped that the results of this study encourage those institutions to consider innovative alternatives to enhance the skills of their students by promoting the permanent growth and reflective practice of their teachers. Hopefully by doing that, they will be taking an important step towards reducing the gap existing in Colombia between the high class and the lower and middle classes in terms of bilingualism and future job opportunities.

\section{References}

Acheson, K., \& Damien, M. (2003). Clinical Supervision and Teacher Development. Preservice and Inservice Applications. United States. Edit John Wiley and Sons.

Ariza, V. (2014, September). Setting up the Context for reflection: Video Recording and Teacher's Training. Paper presented at the VI Colloquium in Foreign Language Research. Universidad Nacional de Colombia, Bogotá.

Bailey, K. (2006). Language Teacher Supervision: A case based approach. New York. Cambridge University Press.

Bogoya, D. (2013). Elementos de Calidad de la Educación Superior en Colombia. Caso de Estudio Universidades. Retrieved from http://static.elespectador.com/archivos/1309-estudio-saber-pro.pdf

Díaz, G. (2014). "Every teacher a Leonardo: Research as a form of identity construction. Paper presented at the VI Colloquium in Foreign Language Research. Universidad Nacional de Colombia, Bogotá.

Education First. English Proficiency Index. (2013, 10, 08). Retrieved from http://www.ef.com.co/epi/

Education World. Guidance from the Get-Go: Mentoring New Teachers. (2014). Retrieved from 
$\mathrm{http}: / /$ www.educationworld.com/a_admin/admin/admin260.shtml

Feiman, S. (2003). What teachers need to learn. Leadership. Association for Supervision and Curriculum Development. Retrieved from https://www.stcloudstate.edu/tpi/initiative/documents/preparation/What\%20New\%20Teachers\%20Need\%2 0to\%20Learn.pdf

Fernández, S. (2009). América latina de cara al mundo: Políticas lingüísticas y Enseñanza de Lenguas para un mundo globalizado. University of Aarhus, Denmark. Latin American Centre. Retrieved from http://lacua.au.dk/fileadmin/www.lacua.au.dk/publications/15_di_logos_latinoamericanos/Full_Version_15. pdf

Fluckiger, J., McGlamery, S., \& Edick, N. (2006). Mentoring Teacher's Stories: Caring Mentors Help Novice Teachers Stick with Teaching and DevelopExpertise. University of Nebraska. Retrieved from $\mathrm{http} / /$ digitalcommons.unomaha.edu/cgi/viewcontent.cgi?article=1006\&context=tedfacpub

Gonzalez, N. Lineamientos teórico metodológicos de acompañamiento docente para la práctica pedagógica (2014) Retrieved from http://publicaciones.urbe.edu/index.php/telos/article/view/1202/2493

Gutierrez, E. (2007). Las Grabaciones en Video de secuencias didácticas como instrumento de Observación, Análisis y Reflexión para la Evaluación de la Práctica Docente. Retrieved from: http://cvc.cervantes.es/ensenanza/biblioteca_ele/asele/pdf/18/18_0611.pdf

Hernández, Fernández y Baptista. (2010). Metodología de la Investigación. México D.F. Mc Graw Hill.

Iowa State University. Student Evaluation of Teaching. (2014). Retrieved from http://www.celt.iastate.edu/teaching-resources/document-your-teaching/student-evaluation-of-teaching/sam ple-questions/

Koffman, E., Mckeely, S., \& Willerman, M. (1991). Teachers Helping Teachers: Peer Observation and Assistance Hardcover. The Journal of Special Education. New York. United States.

Lemos, C. (2014). Resultados Pruebas Saber Pro. Retrieved from http://facultades.uniguajira.edu.co/educacion/index.php?option=com_wrapper\&view=wrapper\&Itemid $=184$

Mata, S., Fossi, L., Castro, L., \& Guerrero, W. (2008). Formación de formadores en la universidad. Orbis Journal. Retrieved from http://www.redalyc.org/articulo.oa?id=70930907

Ministerio de Educación Nacional de Colombia. (2015). Guía 22. Estándares Básicos de Competencias en Lengua Extranjera. Retrieved from http://www.colombiaaprende.edu.co/html/micrositios/1752/articles-315518_recurso_3.pdf

Ministerio de Educación Nacional de Colombia. Mejores Universidades de Colombia, según las Pruebas Saber Pro 2012. Retrieved from http://www.mineducacion.gov.co/cvn/1665/w3-article-328609.html

Ministerio de Educación Nacional de Colombia. Programa Nacional de Inglés 2015 - 2025 "Colombia Very Well”, Documento de Socialización. (2014, 07, 31) Retrieved from http://www.colombiaaprende.edu.co/html/micrositios/1752/articles-343287_recurso_1.pdf

Ministerio de Educación Nacional de Colombia. (2015). Programa Nacional de Bilinguismo. Retrieved from $\mathrm{http} / / / \mathrm{www} . c 0 l o m b i a a p r e n d e . e d u . c o / h t m l /$ productos/1685/article-158720.html

Miranda, I. (2014). Implementación del Plan Nacional de Bilingüismo: El docente de lenguas, el autor olvidado. Paper presented at the VI Colloquium in Foreign Language Research. Universidad Nacional de Colombia, Bogotá.

Pozo, M. (2009). La Enseñanza de Lenguas Extranjeras en Argentina. University of Aarhus, Denmark. Latin American Centre. Retrieved from http://www.redalyc.org/pdf/162/16220868002.pdf

Rodriguez, A. (2013). Informe pruebas saber pro. Retrieved from https://www.google.com.co/\#q=PRUEBAS+SABER+PRO+UNIMAGDALENA

Rodriguez, A. (2008). Hacia una visión prospectiva de la gerencia y supervisión educativa. Upel Journal. $\begin{array}{llll}\text { Research and Postgraduate } & \text { studies. } & \text { Retrieved } & \text { from }\end{array}$ http://revistas.upel.edu.ve/index.php/revinpost/article/viewfile/887/329

Sánchez, A. (2013). Bilingüismo en Colombia. Centro de Estudios Económicos Regionales. Banco de la Republica. http://www.banrep.gov.co/sites/default/files/publicaciones/archivos/dtser_191.pdf?_utma=1.1290233652.1 
429921211.1429921211.1429921211.1\& utmb=1.2.10.1429921211\& utmc $=1 \& \quad$ utmx $=\& \quad$ utmz $=1.14$ 29921211.1.1.utmcsr $=$ google $\mid$ utmcen $=($ organic $) \mid$ utmcmd $=$ organic $\mid$ utmctr $=($ not $\% 20$ provided $) \&$ utmv $=-\&$ utmk=109981957

Sánchez, M. (1993). La supervisión Clínica como estrategia de formación de profesores mentores y principiantes. Doctoral Dissertation. $\quad$ Retrieved from http://fondosdigitales.us.es/tesis/tesis/631/la-supervision-clinica-como-estrategia-de-formacion-de-profesor es-mentores-y-principiantes/

Sullivan, S., \& Jeffrey, G. (2013). Supervision that improves teaching: Strategies and Techniques. United States. Edit. Corwin Press

Tanner, D., \& Tanner, L. (1987). Supervision in Education: Problems and practices. New York. Edit. Macmillan

The Alberta Teacher's Association. (2013). Mentoring Beginning Teachers. Program Handbook. Retrieved from http://www.teachers.ab.ca/SiteCollectionDocuments/ATA/Publications/Professional-Development/Mentorin g_Beginning_Teachers.pdf

UNESCO. Las Lenguas en la Educación. Retrieved from http://www.unesco.org/new/es/education/themes/strengthening-education-systems/languages-in-education/s trategy/

University of California. (2015). Teachers' assessment. Retrieved from http://www.oid.ucla.edu/assessment/eip/measure

U.S Department of Education. (2015). On Task Technique and Video Tape Reflection. Retrieved from http://www.d214.org/human_resources/observation_techniques_and_forms1.aspx

Waite, D. (2015). Educational Supervision: Perspectives, Issues and Controversies. Retrieved from https://www.researchgate.net/profile/Duncan_Waite/publication/280360153_Do_Teachers_Benefit_From_S upervision_No/links/55b349bb08ae9289a0859d2e.pdf

Waite, D. (2009). Supervisión Clínica. Retrieved from http://www.raco.cat/index.php/educar/article/viewFile/200833

\section{Copyrights}

Copyright for this article is retained by the author(s), with first publication rights granted to the journal.

This is an open-access article distributed under the terms and conditions of the Creative Commons Attribution license (http://creativecommons.org/licenses/by/4.0/). 